\title{
Assessment of pupils' physical activity during diverse types of teaching lessons
}

\author{
Marek Trávnícek', Hana Svobodová , Radek Durna ${ }^{2}$ \\ ${ }^{\prime}$ Department of Physical and Health Education, Faculty of Education, Masaryk University, Brno, Czech Republic \\ ${ }^{2}$ Department of Geography, Faculty of Education, Masaryk University, Brno, Czech Republic
}

\begin{abstract}
This paper focuses on the physical activity of pupils of early school age during different types of school lessons, i.e., 45 minutes - a frontal teaching lesson, a physical education lesson, and an integrated fieldwork education (IFE) lesson. In the research, we analyzed each method of teaching regarding the number of steps the pupils made and their metabolic rate in MET units. The secondary aim was to verify the use of ActiGraph accelerometers by teachers at schools and to provide basic information about the devices to the potential users.

The physical education class had the highest volume of movement - 1,202 steps in 45 minutes. However, the IFE with 1,118 steps in 45 minutes may be compared to a class of physical education in terms of the number of steps. The weakest regarding the steps made and the amount of physical activity was a regular education class, where students walked an average of 218 steps in 45 minutes. We also tried to find out the intensity of the physical load of pupils of early school age. Again, the physically most demanding form of teaching was the physical education lesson, during which pupils achieved medium physical load above 3 MET. For integrated fieldwork education, the metabolic output was below 3 MET, namely 2.63. The lesson of formal teaching was characterized by a low-intensity motoric load of $1.81 \mathrm{MET}$.
\end{abstract}

Keywords: ActiGraph, accelerometer, pupils' physical activity, metabolic rate, motoric load, school education, physical education, integrated fieldwork education.

Acknowledgments: This work was supported by the Czech Science Foundation grant 16-00695S Fieldwork as a Powerful Learning Strategy.

\section{INTRODUCTION}

This paper discusses the topic of physical activity of children, especially the physical activity and a motoric load of early school age pupils (circa 10 years old) during a school lesson. Physical activity is an integral part of human life and one of the important needs of every man. The contemporary trends in the context of consumerist sedentary society and its negative influence on decreasing of physical activity describes Sekot (2016) and Neumann (2000). That is why in recent time both in the Czech Republic and worldwide, many authors applied themselves to movement routine of pupils in their research. Mužík and Krejčí (1997) recommend 30 minutes of a lower intensity movement activity a day, to which 30 minutes of medium intensity movement should be added at least 3 times a week. As compared to Mužík, the demands of Sigmund and Sigmundová (2011) for the daily movement activity of early school age children are significantly higher. In their opinion, the medium intensity daily movement activity of children should be 3 times longer, i.e. 90 minutes. An adequate volume of daily movement activity serves for maintaining aerobic prowess in children. Frömel (1996) states that during physical education lessons at school pupils can fulfill the minimum motoric load, provided responsible personnel and adequate conditions 
are secured, although this can also be arranged in other than physical education lessons. In addition to physical education at school, early school-age children can come close to the minimum motoric load within various free-time activities during the day.

It follows from the above that it is advisable to increase the percentage of pupils' movement in pupils, and by means of various physical activities to support their interest in movement already at an early age, both in the school environment and beyond the designated physical education lessons, for example by integrating the individual school subjects precisely with physical education. For these reasons, progressive, activating forms of teaching, like integrated fieldwork education, present themselves. Through fieldwork education, it is possible to achieve natural implementation of movement activity directly into the instruction of various subjects. Connecting movement activities with the educational content of various subjects are supposed to have positive effects on the motoric routine of elementary school pupils (Trávníček, 2010).

Průcha (2013) characterizes integrated education as teaching implementing cross-curricular relationships and connecting theoretic activities with practical ones. This education takes place mainly in the forms of integrated subjects or courses, modules or themes build into more subjects, projects linking the findings from several subjects with practical experience. The integrated curriculum makes it possible for pupils to get to know the world as a whole, and Pruicha (2013) advances the point that this type of curriculum is traditional especially at the primary grades of elementary schools.

One of the first steps in the integration of physical education with another subject in our country is international cooperation in researching the possible integration of physical education and geography (Vlček et al. 2016). The use of the authentic environment for instruction presents itself in the course of useful introduction of integrated teaching. In the transfer of integrated education beyond school desks - into the field, we easily achieve integration of movement activity into teaching, while we also obtain a natural environment for the integration of the other subjects. Following this guide, we afford the pupils a clearer outlook of the content of the curriculum and an easier understanding of the relations among the individual branches. Therefore, we encounter with the term fieldwork education. In foreign literature, fieldwork education has been considered a compelling teaching strategy for many years, both for understanding the today's world (see e.g. Balderstone and Lambert 2012, or Oost et al. 2011) and for the development of the key competencies - for learning, problem-solving, social, personal, and communicative competences. It is specific for many scientific disciplines and humanities, but the connection with physical education is also logical.

According to Hofmann (2003, p. 7), integrated fieldwork education is a sophisticated form of instruction that encompasses various teaching methods (experiment, laboratory tasks, observation, project method, cooperative methods, adventure educational methods...) and various organisational forms of instruction (outings, field exercises, excursions, thematic school trips expeditions), while the focus of this form of instruction is on the work in the field, primarily out of the school building. The contribution follows on a long-term successful practice and a research related to integrated fieldwork education, especially at the Faculty of Education of Masaryk University (Hofmann, Trávníček, \& Soják, 2011; Korvas 2009), where investigation has proven that integrated fieldwork education is an equal form of school teaching, and it can have a significant share in integration of either two or more subject.

Therefore, integrated fieldwork education appears to be an effective form of teaching, offering a unique option to integrate physical activity in the education of geography, biology and other disciplines like history.

Integrated fieldwork education is outdoor teaching, in the course of which we employ the subject matter of several teaching subjects and the methods typical for these subjects of study in such 
a way that the resulting compact teaching support the pupils' development in the social, personal, and cognitive dimension. Cognitive learning or acquiring information on the world, recognizing the relations among individual subjects, and their subsequent application in practice can take place both in the classroom environment and during work in the field. Motoric teaching, however, is rarely a part of the educational process in the classroom. If there is one, it often remains at the level of fine motor skills development. Often, we are unable to secure gross motor skills, prowess, stamina, and other movement skills during teaching in the classroom; hence especially physical education lessons can develop this dimension of personality. Nevertheless, if teachers transfer teaching from the classroom in the outdoor, they have much more space and options to implement motoric learning. Integrated fieldwork education offers a wide scale of spheres teachers can develop by applying this form of teaching even beyond physical education lessons.

The objective of this paper is to find out and compare the physical load in early school-age children during three types of school lessons, namely a habitual lesson in the form of frontal teaching, a physical education lesson and a lesson of integrated fieldwork education (IFE).

The measured quantities are the metabolic rate in MET values and the number of steps. The partial goal of the work is to verify the use of ActiGraph accelerometers in monitoring the physical activity in early school age children in the school environment and to provide basic information on the functionality of measuring children using these devices.

\section{METHODS}

The objective of the research was to ascertain the intensity of the physical load in early school age pupils attending a selected elementary school in Brno during various forms of teaching, namely a habitual education lesson, a physical education lesson, and a lesson of integrated fieldwork education. The acquired data were compared in the form of case studies for individual pupils. The intentional selection was applied to choose the pupils of the grade 4 at a model elementary school. Because of the limitation imposed by the number of monitoring devices to be used for the research, our sample contained 10 probands out of the total number of 24 pupils in the class. The ten probands were determined by applying stratified sampling. The core set was divided into two groups for equal representation of boys and girls in the sample. Therefore it comprised 5 boys and 5 girls. The physical load in early school-age children was monitored using ActiGraph accelerometers. The use of accelerometers for measurement of physical activity was recommended, e.g. by Stará and Vespalec (2017). Out of the functions, these instruments can measure, in our research we concentrated on the number of steps in the selected forms of teaching, pulse rate, and metabolic rate in $\mathrm{MET}^{1}$ units, where 1 MET equals to energy cost in passive sitting position. Measurements were complemented with a structured interview to find out the teacher's opinion regarding the monitoring of physical load of her pupils using accelerometers, and especially the possible limitations on the pupils resulting from wearing the devices during various activities. The second observed sphere was the incorporation of integrated fieldwork education into the teaching of the respective class, and the content of integrated fieldwork education.

To find out the attitudes of children towards the convenience in wearing the instruments and outdoor teaching and the interest of children in this non-traditional form of teaching, brief questionnaires were created to make the information on measurement complete. The measured values of a number of steps and metabolic rate in MET units for the same time interval in indi-

\footnotetext{
${ }^{1}$ A MET is the ratio of the work metabolic rate to the resting metabolic rate. One MET is defined as $1 \mathrm{kcal} / \mathrm{kg} /$ hour and is roughly equivalent to the energy cost of sitting quietly. For example: the energy cost of playing rugby is 8.3 METS, which means you use 8.3 times more energy than if you were to sit quietly and rest (METS, 2016 online)
} 
vidual probands were averaged and compared in a table. The measured data from all habitual education lessons from 3 days of measuring, were averaged to create a representative lesson of this from of education for each pupil separately. The same method was applied in the processing of results obtained during integrated fieldwork education. The data for all breaks were averaged at the number of steps per 1 minute and subsequently multiplied by 45 to provide relevant results.

\section{RESULTS}

The interview with the class teacher was carried out towards the end of the investigation, after the implementation of fieldwork education. The teacher declared that the monitoring devices put no limits on her preparation for teaching, and she felt no major limitations during her teaching either. In her response, the teacher also corroborated the above advantages of fieldwork education, specifically adventure learning, due to which subject matter can become strengthened in pupils more easily.

The questionnaire was distributed to pupils participating in the research after the termination of all measurements. It follows from the outcomes obtained from the pupils using the questionnaires that initially half of the pupils had problems with attaching the instruments, and they needed to be helped by an adult. Sixty percent of children designated the upper chest belt as less comfortable. After resetting and adjustment of the belt especially children with smaller chest girth designated the belt as uncomfortable, although it was not a limiting factor in the teaching. The questionnaire also dealt with the implemented integrated fieldwork education. Eighty percent of pupils unambiguously answered they found fieldwork education entertaining, and its effectiveness was verified using the so-called film strips when pupils in art lessons recorded the subject matter (development stages of frogs) in the correct sequence within a twelve-day lapse of time from outdoor teaching. The monitored pupils created the correct development cycle with all important stages; hence it can be stated that during the implementation of integrated fieldwork education no deterioration of results of learning occurred.

Average measured data relating to the individual lessons, namely a habitual education class, physical education lesson, and integrated fieldwork education are presented below. The table below (Tab. 1) indicates the average numbers of steps obtained from measuring all of the 10 probands in selected lessons during 45 minutes of the teaching.

Tab. 1: Comparison of the average number of steps during selected lessons ( 45 minutes)

\begin{tabular}{|c|c|c|c|}
\hline & Habitual lesson & PE lesson & IFE lesson \\
\hline Average number of steps & 218 & 1202 & 1118 \\
\hline Max no. of steps & 364 & 2020 & 1160 \\
\hline Min no. of steps & 116 & 673 & 800 \\
\hline
\end{tabular}

It is evident from the average values that the number of steps during integrated fieldwork education is more than five times higher than during habitual teaching. If we consider an integrated fieldwork education lesson and a physical education lesson, however, we have to state the difference of nearly 100 steps in favor of the physical education lesson. Because of the total number of steps, it is possible to state that from the point of view of the movement activity volume these two forms of teaching are almost comparable. 


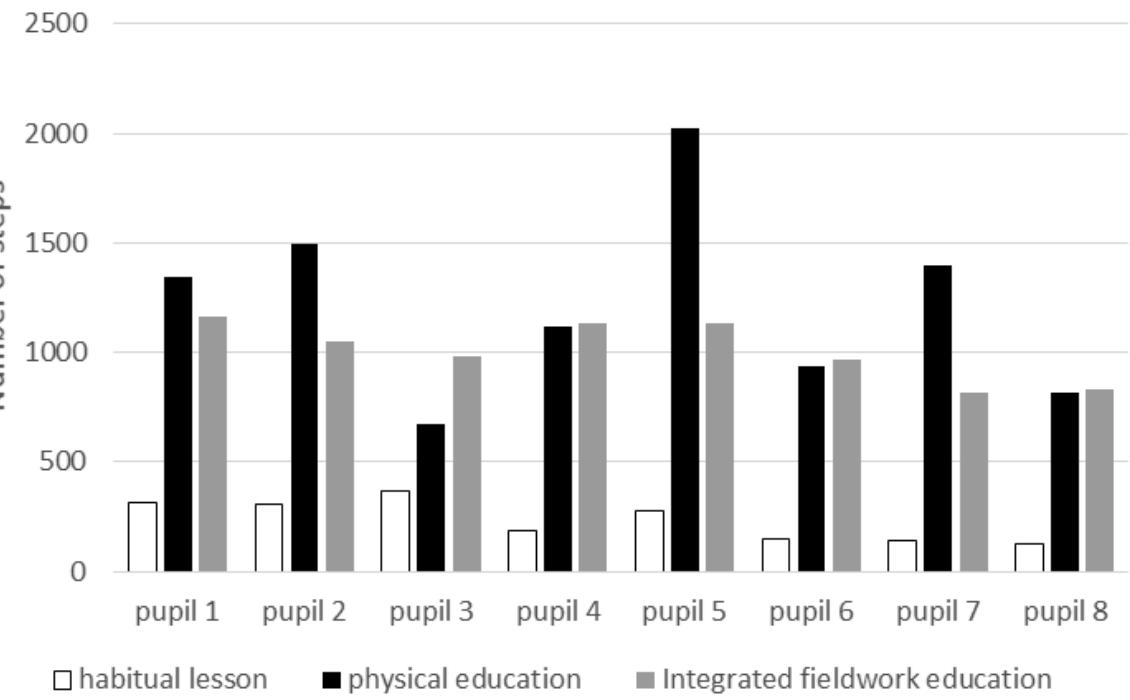

Fig. 1 Number of steps during selected lessons (45 minutes) for individual pupils

Of course, the number of steps strongly depends on educational activity realized during the lesson and on physical activeness of each pupil. The deeper individual analysis of each pupil shows that some pupils made more steps during integrated fieldwork education than during the PE lesson (Fig. 1). Moreover, against the physical education lesson, a doubtless advantage of integrated fieldwork education is the transfer of the specialist subject matter to the pupils (at the 1st grade most often national history and geography, natural science within educational sphere Man and the World).

The table below (Tab. 2) presents the measured values of metabolic rate. Average values obtained from all pupils participating in the research are presented.

Tab. 2: Comparison of average values of metabolic rate during selected lessons ( 45 minutes)

\begin{tabular}{|c|c|c|c|}
\hline & Habitual lesson & PE lesson & IFE lesson \\
\hline Average metabolic rate (METs) & 1.81 & 3.46 & 2.63 \\
\hline Max metabolic rate (METs) & 6.64 & 8.10 & 7.73 \\
\hline Min metabolic rate (METs) & 1.00 & 1.00 & 1.00 \\
\hline Median metabolic rate (METs) & 1.80 & 3.23 & 2.45 \\
\hline
\end{tabular}

The following diagram (Fig. 2) illustrates the average values of the motoric load in all probands recorded in the individual types of teaching. 


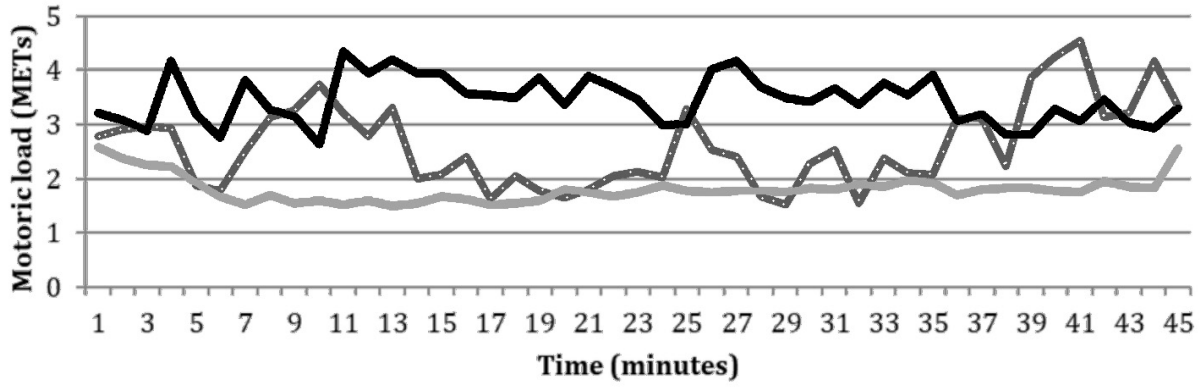

m...integrated fieldwork education $\quad$ physical education $\quad$ frontal teaching

Fig. 2 Behaviour of the average values of the motoric load in all probands recorded in the individual types of lessons (45 minutes)

If we compare the individual lessons on the grounds of average metabolic rate, we conclude that during IFE average values increase, but so do the maximums as against a habitual lesson. Average intensity of motoric load during integrated fieldwork teaching, however, ranges between the average value of the metabolic rate of a habitual lesson and a physical education lesson; therefore, in comparing IFE with a PE lesson in our research, the physical education lesson comes out as better. Since there is a number of ways how to conceive integrated fieldwork education, depending on the contents, but also the environment where it is performed, quite possibly the reason of obtained outcomes is exactly the uniqueness of the integrated fieldwork education we implemented within our investigation.

If we consider an average school day consisting of 5 lessons, of which 4 lessons are devoted to teaching of a habitual character, and the remaining lesson is always one of the monitored lessons, the comparison of the individual types of days, i.e., a day with a habitual education lesson, a day with a physical education lesson, and a day with integrated fieldwork education, is consistent with the comparison of the individual forms of teaching. For the pupils of the selected school in Brno the most beneficial type in terms of movement activity appears to be the day comprising a physical education lesson; nevertheless, integrated fieldwork education is a comparable substitute to the physical education lesson. If we ensue from the division of outdoor education from the perspective of time after Hoffman (2003), IFE should take at least two hours. Therefore, in case we implement two lessons of integrated fieldwork education in a school day, this type of day would be more beneficial for the selected pupils regarding movement activity, as stated in the table below (Tab. 3).

Tab. 3: Comparison of the individual types of days from the perspective of a number of steps and metabolic rate

\begin{tabular}{|c|c|c|c|c|}
\hline & $\begin{array}{c}\text { Day } \\
\text { of habitual teaching }\end{array}$ & $\begin{array}{c}\text { Day with } \\
\text { a PE lesson }\end{array}$ & $\begin{array}{c}\text { Day with } \\
\text { an IFE lesson }\end{array}$ & $\begin{array}{c}\text { Day } \\
\text { with two IFE lessons }\end{array}$ \\
\hline Number of steps & 1090 & 2074 & 1990 & 2890 \\
\hline $\begin{array}{c}\text { Average metabolic } \\
\text { rate (MET) }\end{array}$ & 1.810 & 2.140 & 1.970 & 2.640 \\
\hline
\end{tabular}

It follows from the stated data that integrated fieldwork education and a physical education lesson alike increase both intensity and volume of movement activity within a school day, and it is evident that long-time IFE has a very decisive impact on the motoric load of the pupils. 


\section{DISCUSSION}

Looking at the results of the research we can state that a lesson of integrated fieldwork education is almost equal to a physical education lesson in terms of movement activity measured by means of a number of steps. In their book of 2009, Korvas and Cacek of the Faculty of Sports Studies, Masaryk University indicate that for pupils of the grade 2 level of an elementary school a lesson of integrated fieldwork education is comparable to a physical education lesson regarding a number of steps. Therefore, we can say we have extended the conclusions of the above scientists to also include the selected pupils of early school age. With the low quantity of probands and an absence of a deeper analysis, the obtained results cannot be generalised, although the measured data allow observation of certain tendencies that corroborate our assumptions regarding the volume and intensity of movement activity in the school environment.

Since integrated fieldwork education comprises two constituents, motoric and educational, there are many different concepts of this form of teaching. Therefore, in drawing these conclusions, it is necessary to bear in mind that the two types of lessons (integrated fieldwork education and physical education) may not always meet the measured data. Additionally, it is important to realize that knowledge, hence the effectiveness of IFE, is an equally important constituent of this form of teaching as its motoric component. Therefore, the motoric constituent should never surpass the educational one.

From the perspective of the intensity of the physical load, the values achieved during an average outdoor lesson range exactly between the values measured during a habitual lesson and a physical education lesson. Therefore, integrated fieldwork education is potentially a form of teaching with a greater motoric intensity than a habitual lesson, and at the same time, no deterioration of results occurs during IFE.

Implementation of movement activity measuring is not based only on the need to prove inadequate movement activity of school-age pupils, but also on the need to strengthen the role of (integrated) fieldwork education in the Czech schools. Whereas foreign research in the sphere of outdoor teaching have already proven the positive impacts of fieldwork educational activities on teaching (Neil, Richards 1998), described the factors hampering the implementation of outdoor education (Waite 2009), or dealt with the importance of fieldwork education for cognitive and affective development of pupils (Mygind 2009), in the Czech Republic this research has only just started within the Czech Science Foundation project "Fieldwork Education as a Powerful Teaching Strategy" (GAČR 16-00695S Fieldwork as a powerful learning strategy). Thus far there is no coherent awareness of incorporating fieldwork education into school curricula or the real implementation of outdoor education at basic and secondary schools, and for instance, its influence on the movement activity and healthy lifestyle was studied only marginally (Korvas 2009).

\section{CONCLUSION}

The objective of the research was to compare three types of school lessons, which differ in the application of various forms of teaching. The forms we included in our investigation are habitual education, physical education, and integrated fieldwork education. Selected lessons were compared from the perspective of movement activity volume, i.e., the number of steps made by individual pupils and their metabolic rate, i.e., the amount of motoric load. ActiGraph accelerometers were used to measure these parameters.

The highest average number of steps was achieved during physical education lesson; contrariwise, habitual education lesson resulted in the lowest number of steps. Furthermore, we tried 
to ascertain the physical load intensity amount of teaching the early school age pupils. Again, the physically most demanding form of teaching was physical education lesson, the integrated fieldwork education lesson was somewhat less demanding, and habitual education class was characterized by a low motoric load intensity. All types were completed with the description of strengths and weaknesses of measuring using ActiGraph instruments. To this end, a questionnaire was created and an interview made with the class teacher, complemented by our experience with the instruments. A doubtless advantage of the ActiGraph instruments is easy handling of the devices, i.e., their setting prior to both measuring and upload of data; each investigator should become thoroughly acquainted with this beforehand. The main drawbacks of measuring using these instruments include the manner of fastening or the discomfort caused by the fastening belts and their inappropriate length, or an inappropriate length of the belt for measuring of early school age pupils and children of delicate bodies.

\section{References}

Frömel, K., Svozil, Z., \& Novosad, J. (1999). Pohybová aktivita a sportovní zájmy mládeže: [monografie pro studijní účely]. Olomouc: Univerzita Palackého.

Hofmann, E. (2003). Integrované terénní vyučování. Brno: Paido.

Hofmann, E., Trávníček, M., \& Soják, P. (2011). Integrovaná terénní výuka jako systém. In Smíšený design v pedagogickém výzkumu: Sborník příspěvků z 19. výroční konference České asociace pedagogického výzkumu (pp. 310-315). Masaryk University Press. https://doi.org/10.5817/PdF.P210-CAPV-2012-11

Korvas, P., \& Cacek, J. (2009). Integrovaná výuka a tělesná výchova na základní škole. Brno: Masarykova univerzita.

Lambert, D., \& Balderstone, D. (2012). Learning to teach geography in the secondary school: a companion to school experience. Routledge.

METS. BrainMAC Sports Coach [online]. 2016 [cit. 2017-06-22]. Available at: https://www.brianmac.co.uk/mets.htm

Mužík, V., \& Krejčí, M. (1997). Tělesná výchova a zdraví: zdravotně orientované pojetí tělesné výchovy pro 1. stupeň ZŠ. Olomouc: Hanex.

Mygind, E. (2009). A comparison of childrens' statements about social relations and teaching in the classroom and in the outdoor environment. Journal of Adventure Education \& Outdoor Learning, 9(2), 151-169.

Neill, J. T., \& Richards, G. E. (1998). Does outdoor education really work? A summary of recent meta-analyses. Australian Journal of Outdoor Education, 3(1).

Neumann, J. (2000): Dobrodružné hry a cvičenív prírodě. 3rd edition. Praha: Portál. 325 p.

Oost, K., De Vries, B., \& Van der Schee, J. A. (2011). Enquiry-driven fieldwork as a rich and powerful teaching strategyschool practices in secondary geography education in the Netherlands. International Research in Geographical and Environmental Education, 20(4), 309-325.

Podroužek, L. (2002). Integrovaná výuka na základní škole v teorii a praxi. Plzeň: Fraus.

Průcha, J. (2013). Moderní pedagogika (5., aktualiz. a dopl. vyd.). Praha: Portál.

Sekot, A. (2016). Pohybové aktivity v kontextu konzumní sedavé společnosti. Studia Sportiva, 10(2), 8-18.

Sigmund, E., \& Sigmundová, D. (2011). Pohybová aktivita pro podporu zdraví détí a mládeže. Olomouc: Univerzita Palackého $\checkmark$ Olomouci.

Stará, J., \& Vespalec, T. (2017). Hodnocení individuální míry pohybové aktivity dotazníky IPAQ a Wellness Inventory: případová studie. Studia Sportiva, 11(1), 44-52.

Trávníček, M. (2010). ACTIV - projekt integrované terénní výuky ve studiu učitelství. In V. Mužík \& P. Vlček, Škola, pohyb a zdraví: výzkumné výsledky a projekty (pp. 193-199). Brno: Masarykova univerzita.

Vlček, P., Resnik Planinc, T., Svobodová, H., \& Witzel Clausen, S. (2016). Integrating physical education and geography: a case study of the Czech Republic, Slovenia and Denmark. Brno: Masaryk University.

Waite, S. (2009). Outdoor learning for children aged 2-11: Perceived barriers, potential solutions. In Fourth International Outdoor Education Research Conference, La Trobe University, Beechworth, Victoria, Australia (pp. 15-18). 